\title{
Unequal Rewards to Firms: Stock Market Responses to the Trump Election and the 2017 Corporate Tax Reform
}

\author{
Wagner, Alexander ; Zeckhauser, Richard J ; Ziegler, Alexandre
}

\begin{abstract}
Massive dollars shuttled back and forth among firms on the twisted path to and passage of the 2017 tax reform. Prices of individual stocks responded to the difference between initial and revised expectations. From the bill's initiation in the House to final passage, high-tax firms gained significantly, given the dramatic cut from $35 \%$ to $21 \%$ in the corporate tax rate. Internationally-oriented firms suffered notably, since investors assessed that the surprisingly high repatriation tax outweighed the benefits from territorial taxation. Daily price movements show that the aggregate market responded positively to lower expected taxes.
\end{abstract}

DOI: https://doi.org/10.1257/pandp.20181091

Posted at the Zurich Open Repository and Archive, University of Zurich ZORA URL: https://doi.org/10.5167/uzh-169713

Journal Article

Published Version

Originally published at:

Wagner, Alexander; Zeckhauser, Richard J; Ziegler, Alexandre (2018). Unequal Rewards to Firms: Stock Market Responses to the Trump Election and the 2017 Corporate Tax Reform. American Economic Association. Papers and Proceedings, 108(May):590-596.

DOI: https://doi.org/10.1257/pandp.20181091 


\title{
Unequal Rewards to Firms: Stock Market Responses to the Trump Election and the 2017 Corporate Tax Reform ${ }^{\dagger}$
}

\author{
By Alexander F. Wagner, Richard J. Zeckhauser, And Alexandre Ziegler*
}

Massive dollars shuttled back and forth among firms on the twisted path to and passage of the Tax Cuts and Jobs Act of 2017 (TCJA). ${ }^{1}$ Prices of individual stocks responded as expectations got revised. The path started with a jolt: Donald Trump's surprise election. The immediate relative stock price response confirmed the widespread view that corporate taxes would go lower, and that trade practices would be more restrictive. Nothing draconian was done with trade arrangements in 2017. Similarly, little was determined on the fate and form of any tax legislation through the first ten months of 2017. In the last two months, Congress got busy, and the TCJA became law on December 22, 2017.

This paper investigates two questions. First, how did individual stock prices move in those last two months as the prospects for tax reform waned and waxed, and its contents shifted? Second, to what extent was the (anticipated and actually implemented) tax reform responsible for the steep increase in the stock market from the election through the end of 2017 ?

\footnotetext{
*Wagner: University of Zurich and Swiss Finance Institute (email: alexander.wagner@bf.uzh.ch); Zeckhauser: Harvard University and NBER (email: richard_zeckhauser@ harvard.edu); Ziegler: University of Zurich (email: alexandre.ziegler@bf.uzh.ch). We particularly thank Larry Summers and participants at the American Economic Association Annual Meeting 2018 (session on "What can we learn from financial market responses to the 2016 election?") for comments. Wagner thanks the Swiss Finance Institute and the University of Zurich Research Priority Program Financial Market Regulation for financial support. Wagner is chairman of the board of trustees of SWIPRA and an independent counsel for PricewaterhouseCoopers.

${ }^{\dagger}$ Go to https://doi.org/10.1257/pandp.20181091 to visit the article page for additional materials and author disclosure statement $(\mathrm{s})$.

${ }^{1}$ The legislation was passed under the name "Tax Cuts and Jobs Act" by the House, but had to be renamed "An Act to provide for reconciliation pursuant to titles II and $\mathrm{V}$ of the concurrent resolution on the budget for fiscal year 2018" to comply with Senate rules. We shall nevertheless refer to it as the TCJA throughout the paper for convenience.
}

It is important to note that major uncertainties persisted until the end: Would a bill pass? Which corporate tax rate would apply? When would tax cuts go into effect? What tax rate would apply to unremitted foreign earnings? Would there be territorial or worldwide taxation of corporate profits? The final answers were yes to passage, a 2018 initiation date for a 21 percent federal corporate tax rate, a tax of 15.5 percent on previously untaxed foreign earnings held in cash, and territorial taxation. The analysis particularly attends to individual stock movements immediately after game-changing events such as the introduction of the tax bill in the House on November 2 and the Senate passage of a revised bill on December 2.

From the bill's release from the House Ways and Means Committee on November 2 until final passage, high-tax firms gained significantly, given the dramatic cut in the corporate tax rate. Internationally oriented firms suffered notably, presumably because investors assessed that the surprisingly high repatriation tax (which increased repeatedly through the process) outweighed the benefits from territorial taxation.

We examine the relationship between tax cuts and overall market moves. From Trump's election until the TCJA's passage, on those days when high-tax firms outperformed (underperformed) low-tax firms the market tended to move upward (downward). The effect is sizable: A one standard deviation greater sensitivity of stock returns to taxes on a given day was associated with a 0.15 percentage points (or 33 percent of a standard deviation) increase in market returns.

\section{The Path to the Tax Cuts and Jobs Act}

Corporate taxes and trade were key elements of Donald Trump's electoral bid. Thus, it is hardly surprising that after the election, expectations of lower corporate taxes and more 
restrictive trade policies were priced in strongly by the stock market. Investigating the stock market response to the election through the first hundred days of the Trump Administration, Wagner, Zeckhauser, and Ziegler (forthcoming) - henceforth, WZZ - show that high-tax firms and those with large deferred tax liabilities gained; those with significant deferred tax assets from net operating loss carryforwards lost. Domestically focused companies fared better than internationally oriented firms.

While the market did an impressive job pricing in the news of the election, the adjustment to the new world was not easy: Single-firm stock returns exhibited extraordinary momentum for three days in a row after the election, then modestly reversed, before settling at their new equilibrium (Wagner, Zeckhauser, and Ziegler 2018). Homing in on the new equilibrium took several days as the market needed to digest the enormous and multi-faceted surprise outcome of the election. Incomplete information processing regarding tax-related aspects was an important source of momentum.

The significant post-election stock price reaction was overwhelmingly driven by changes in expectations about policies, not policy changes themselves. By the 100-day mark no legislation had been initiated or even sketched on either tax policy or fundamental foreign trade matters. Substantial uncertainty about what would happen in the corporate tax domain persisted post-election for two reasons. First, the Republicans' Senate majority was only two. Second, there were two Republican corporate tax plans going into the election-one from the Trump campaign, and one from the House Republicans. The two differed on a number of dimensions. $^{2}$

\footnotetext{
${ }^{2}$ The two plans agreed on three critical elements: dramatic reduction in the federal statutory rate from its level of 35 percent, the expensing of capital expenditures with a limitation on interest expense deductibility, and an announced intention to tax accumulated foreign earnings. The key differences between them were on the issues of border adjustment, territorial versus worldwide taxation, and net-operating-loss rules (which the Trump plan did not address). Importantly, some aspects of both plans affect multinationals differently from purely domestic firms. Furthermore, while Trump's plan did not include a border adjustment tax, he had repeatedly promoted introducing or increasing tariffs during the campaign, and hinted at other measures to protect American industry.
}

For most of 2017, President Trump and Congress focused on healthcare issues. When legislative efforts in this area failed in late summer, the Congressional Republicans turned to tax reform. From then on, the tax reform moved through the legislative process by both chambers on December 20 and impressively swiftly, making it ideal for an event study. The framework for the reform was released on September 27. The House Ways and Means Committee released a draft bill on November 2 and approved it with amendments on November 9; the House floor passed it on November 16. On the same day, the Senate Finance Committee approved its version of the bill, which was passed in the Senate with amendments on December 2. The House and Senate Conference Committee reached an agreement on December 15. The final TCJA was adopted by both chambers on December 20 and signed into law on December 22.

The bill that ultimately passed contains new elements as well as elements from the original Trump and House Republican plans. The three major provisions on which the Trump and House Republican plans agreed are included in the Act to varying degrees. Specifically, the corporate income tax rate is reduced from 35 percent to 21 percent (against targets of 15 percent in the Trump plan and 20 percent in the House Republican plan). Second, the Act provides for expensing of capital expenditures, increasing the first-year "bonus" depreciation deduction to 100 percent, and allowing corporations to immediately write off the cost of acquisitions of plant and equipment. Third, it limits the deductibility of net business interest expense to 30 percent of adjusted taxable income.

The TCJA also makes fundamental changes to the taxation of multinational entities, shifting from a system of worldwide taxation with deferral to a participation exemption regime with current taxation of certain foreign income. Specifically, the TCJA provides for a 100 percent deduction for dividends received from 10 percent-owned foreign corporations, but introduces a minimum tax on "global intangible low-taxed income" (GILTI) and on certain deductible payments made to foreign affiliates (e.g., royalties and management fees, but excluding cost of goods sold). As a major feature in the transition to the new regime, the TCJA introduces a deemed repatriation of previously untaxed "old earnings" and taxes them 
at much higher rates than envisioned earlier. Specifically, a 15.5 percent rate applies to past earnings held abroad attributable to liquid assets and an 8 percent rate to such earnings attributable to illiquid assets (compared with targets of 8.75 percent and 3.5 percent, respectively, in the House Republicans' plan).

The TCJA comprises many other provisions, such as the indefinite carryforward of net operating losses, depreciating rather than expensing $R \& D$, several elements relevant for cross-border transactions, and an extended holding period for a carried interest to be treated as a long-term capital gain. These factors merit a separate, detailed analysis outside the scope of this paper.

\section{Corporate Taxes and the Cross Section of Stock Returns}

\section{A. Data and Empirical Strategy}

Our empirical strategy regresses abnormal returns (ARs) on "milestone days" during the period leading to the enactment of the TCJA (November 2 to December 22, 2017, henceforth the legislative period) on firm characteristics that proxy for aspects touched upon by the TCJA. It also examines cumulative returns on the same basis. Various provisions of the Act beyond the headline number of the corporate tax rate are likely to differentially affect stocks. We focus on four salient provisions, namely the deductibility of capital expenditures, caps on interest expense deductibility, the shift to territorial taxation, and the tax on accumulated foreign earnings.

The sample includes the Russell 3000 constituents as of the day of the election. ${ }^{3} \mathrm{We}$ exclude companies whose stock prices were below US\$5 on September 30, 2017. We obtain stock prices adjusted for splits and net dividends from Bloomberg and compute CAPM-adjusted returns as in WZZ. ${ }^{4}$ We obtain explanatory variables mostly from Compustat Capital IQ, and use the most current accounting data for all companies. This means the December 31, 2016 data for most companies, though not for several whose

\footnotetext{
${ }^{3}$ The Russell 3000 actually had 2,966 members as of November 8, 2016. A number of firms left the sample by November 2017 due to acquisition or bankruptcy.

${ }^{4}$ The size and value factor returns needed to compute Fama-French adjusted returns are not available at the time of this writing. Returns are reported in percentage points.
}

fiscal years end in another month. For many of the latter, calendar year 2017 data are included. ${ }^{5}$ The cash effective tax rate (cash ETR) is computed as the percent cash taxes paid (adjusted for special items) divided by current year pretax income. ${ }^{6}$ Capital expenditures are expressed in percent of assets. We construct a binary indicator whether interest deductibility would be curtailed for a company (detailed below). Market value of equity is from Bloomberg. The percentage of firm revenue from foreign sources also comes from Bloomberg, and is supplemented by Compustat geographical segment data. We truncate the tax rates and capital expenditure ratios at the 1 percent and 99 percent levels. Descriptive statistics appear in online Appendix Table A-1.

\section{B. Results}

Table 1 shows the results. For space reasons, we only report the explanatory variables meant to capture the effect of the main provisions of the TCJA, and not the control variables employed (market capitalization, revenue growth, profitability, and industry fixed effects).

Consider first the coefficient on the cash ETR, which captures the differential impact of the reduction in the statutory rate on high-tax and low-tax firms. On the day the House Ways and Means Committee introduced a tax reform bill, high-tax firms outperformed. The following two weeks saw relatively little systematic movement. Indeed the ultimate passage vote in the House on November 16 came with a slightly negative return for high-tax firms. A Senate vote awaited, and whether a bill would pass there was highly uncertain given some recalcitrant Republicans and their razor thin majority. When the Senate did vote a bill, albeit one noticeably different from the House bill, high-tax firms prospered. Column 7 shows that over the entire legislative period, the TCJA had a significant relative positive effect on high-tax firms, as expected. Although the tax rate of 21 percent that was ultimately adopted is substantially higher than the 15 percent originally promised by Trump, the latter was not a possibility once legislators got

\footnotetext{
${ }^{5}$ Where Compustat data are missing for the most recent year, they are replaced with prior-year data.

${ }^{6}$ The sample is restricted to those firms with both positive pretax income and an effective tax rate below 100 percent.
} 
Table 1-The Cross Section of Stock Price Reactions to the Tax Cuts and Jobs Act

\begin{tabular}{|c|c|c|c|c|c|c|c|}
\hline \multirow{2}{*}{$\begin{array}{l}\text { Dependent variable: } \\
\text { Time period/event: }\end{array}$} & \multicolumn{7}{|c|}{ CAPM-adjusted returns } \\
\hline & $\begin{array}{l}\text { House bill } \\
\text { introduced } \\
\text { (Nov 2) } \\
(1)\end{array}$ & $\begin{array}{l}\text { Nov } 3 \\
\text { through } \\
\text { Nov } 15 \\
(2)\end{array}$ & $\begin{array}{l}\text { House vote } \\
\text { passed } \\
\text { (Nov 16) } \\
(3)\end{array}$ & $\begin{array}{l}\text { Nov } 17 \\
\text { through } \\
\text { Dec } 1 \\
(4)\end{array}$ & $\begin{array}{c}\text { Senate } \\
\text { vote } \\
\text { passed } \\
(\text { Dec 4) } \\
(5)\end{array}$ & $\begin{array}{l}\text { Dec } 5 \\
\text { through } \\
\text { Dec } 22 \\
(6)\end{array}$ & $\begin{array}{l}\text { Introduction } \\
\text { to signature } \\
\text { (Nov } 2 \\
\text { through } \\
\text { Dec 22) } \\
(7)\end{array}$ \\
\hline Cash effective tax rate (ETR) in percent & $\begin{array}{c}0.016 \\
(0.006)\end{array}$ & $\begin{array}{c}-0.015 \\
(0.015)\end{array}$ & $\begin{array}{r}-0.006 \\
(0.004)\end{array}$ & $\begin{array}{c}0.026 \\
(0.018)\end{array}$ & $\begin{array}{c}0.020 \\
(0.004)\end{array}$ & $\begin{array}{r}-0.009 \\
(0.011)\end{array}$ & $\begin{array}{c}0.039 \\
(0.019)\end{array}$ \\
\hline Percent revenue from foreign sources & $\begin{array}{c}-0.004 \\
(0.004)\end{array}$ & $\begin{array}{c}0.004 \\
(0.008)\end{array}$ & $\begin{array}{c}-0.007 \\
(0.002)\end{array}$ & $\begin{array}{c}-0.038 \\
(0.011)\end{array}$ & $\begin{array}{c}-0.018 \\
(0.002)\end{array}$ & $\begin{array}{c}-0.003 \\
(0.006)\end{array}$ & $\begin{array}{r}-0.059 \\
(0.011)\end{array}$ \\
\hline $\begin{array}{l}\text { Capital expenditures in percent of } \\
\text { total assets }\end{array}$ & $\begin{array}{r}-0.005 \\
(0.032)\end{array}$ & $\begin{array}{c}0.025 \\
(0.065)\end{array}$ & $\begin{array}{c}0.001 \\
(0.016)\end{array}$ & $\begin{array}{c}0.096 \\
(0.086)\end{array}$ & $\begin{array}{c}0.004 \\
(0.026)\end{array}$ & $\begin{array}{r}-0.001 \\
(0.070)\end{array}$ & $\begin{array}{c}0.143 \\
(0.117)\end{array}$ \\
\hline Firm's interest deductibility curtailed & $\begin{array}{c}-0.433 \\
(0.204)\end{array}$ & $\begin{array}{c}0.389 \\
(0.660)\end{array}$ & $\begin{array}{c}-0.145 \\
(0.162)\end{array}$ & $\begin{array}{r}-1.449 \\
(0.762)\end{array}$ & $\begin{array}{c}-0.421 \\
(0.224)\end{array}$ & $\begin{array}{c}0.081 \\
(0.499)\end{array}$ & $\begin{array}{c}-2.288 \\
(0.887)\end{array}$ \\
\hline Observations & 1,466 & 1,466 & 1,466 & 1,465 & 1,461 & 1,461 & 1,460 \\
\hline$R^{2}$ & 0.085 & 0.085 & 0.099 & 0.156 & 0.137 & 0.239 & 0.095 \\
\hline Constant and controls & Yes & Yes & Yes & Yes & Yes & Yes & Yes \\
\hline Industry fixed effects & Yes & Yes & Yes & Yes & Yes & Yes & Yes \\
\hline
\end{tabular}

Notes: This table presents OLS regressions of individual stock returns on the cash ETR, percent revenue from foreign sources, capital expenditures as a percent of total assets, a binary indicator that equals one if interest expenses of a firm exceed 30 percent of EBIT plus interest income, firm-level controls (size, revenue growth, and profitability), and Fama-French 30-industry fixed effects. The time periods covered are indicated in the column headings. The sample includes Russell 3000 firms. Robust standard errors are shown in parentheses.

busy, whereas no tax bill was a real possibility up until the Senate vote.

Early in the legislative period, reform prospects hardly affected internationally oriented firms. The House vote began a slide for multinationals relative to domestically focused companies. This may seem surprising, as the shift to territorial taxation should, ceteris paribus, help multinationals. However, this ceteris lost its paribus. The repatriation tax rate increased progressively: while the original bill from House Ways and Means envisioned 12 percent for previously untaxed foreign earnings held in cash, the House adopted 14 percent, the Senate 14.49 percent, and the Conference Agreement settled on 15.5 percent. As expected, from the House vote until passage, stock of internationally oriented companies were major relative losers.

The new capital expensing provision had little impact on the cross section of stock returns for two reasons. First, existing bonus depreciation rules already allowed a 50 percent deduction in the first year, and full expensing was always in the air. Second, the marginal attractiveness of such expensing decreased given the dramatic cut in the statutory rate. An analysis not shown does reveal that from September 27, the date of the release of the framework for the reform, until the end of December, high-capex firms benefited.

Finally, as expected, firms whose interest expense deductions would be curtailed under the TCJA reacted relatively negatively. ${ }^{7}$

Despite minor anomalies, predictions on how the TCJA would differentially impact firms are borne out by actual stock price movements. It is also noteworthy that the process was not monotonic: in between the major milestones, there were occasional overshoots and reversals. Winners on December 4 (after the Senate vote) lost some of their winnings on December 5

\footnotetext{
${ }^{7}$ Our analysis here uses the rule specified in the Senate version of the bill to determine whether a firm's interest deductibility would be curtailed. Specifically, we define a binary indicator variable equal to one for firms where interest expense exceeds interest income plus 30 percent of EBIT. This limitation is applicable from 2022 onward under TCJA rules. Under the House version of the bill, EBITDA would have been relevant instead, and is applicable initially under TCJA rules.
} 
(analysis not shown). The momentum and reversals were, however, weaker than those in the immediate aftermath of Trump's election as documented in Wagner, Zeckhauser, and Ziegler (2018).

\section{Corporate Taxes and the Aggregate Market}

The preceding analysis focuses on individual companies, establishing the channels through which the TCJA influenced stock prices. But we must consider the forest, not merely the trees, and indeed the forest's lifetime. The rise in the overall stock market is the most dramatic economic development since Trump's election became known. From November 9, 2016 until the end of 2017, the overall stock market, as represented by the Russell 3000 total return index, rose mightily. It was up by 5.82 percent to year-end 2016, and a further 1.46 percent through Inauguration Day. By 100 days into the Trump Administration, the index had appreciated by 13.08 percent from its pre-election level. And by the end of 2017, the index had risen 28.18 percent from just before the election.

The fact that taxes were one of the key drivers of the cross section of stock returns during the period from the election through Trump's first 100 days (see WZZ), and in the run-up to and the passage of the actual tax cut (as documented above), raises a critical question: To what extent did changing expectations and the actual passage of tax reform drive ups and downs in the overall market?

\section{A. Data and Empirical Strategy}

To address this challenging question, we conduct a test inspired by the Fama-MacBeth method. For each of the 287 trading days during the period from November 9, 2016 through the end of 2017, we run a cross-sectional regression of excess stock returns on the cash ETR and control variables, including each stock's exposure to the market, size, and value factors. ${ }^{8}$ Note

\footnotetext{
${ }^{8}$ In this analysis, we use the most current accounting data for all companies applicable at the time of the election. For most companies, this means the December 31, 2015 data, with the exception of firms with fiscal years ending during 2016. Each stock's exposure to the market, size, and value factors is estimated using daily returns from October 1, 2015 through September 30, 2016.
}

that since market moves (and indeed moves in the size and value factors) might themselves be affected by taxes, we use raw excess returns rather than abnormal returns in this analysis. The daily coefficient on each variable reveals the size of the impact that a given stock characteristic had on excess returns that day. In the extended model, we consider percent foreign revenues as well.

An asset-pricing oriented interpretation of this approach is as follows: As is the case in the Fama-MacBeth method, the coefficient on each variable on a given day represents the return on a zero-cost (long-short) portfolio with unit exposure to the variable in question and no exposure to the others. That is why it is important to include the market, size, and value factor exposures as explanatory variables. ${ }^{9}$ Thus, for example, the coefficient estimate on the cash ETR on a given day is the return on that day of a portfolio that is long high-tax firms and short low-tax firms (with the difference in ETR between the long leg and the short leg equal to 1 percentage point) and has no exposure to market, value, size, etc. ${ }^{10}$ (The daily constant thus reflects the return of a portfolio that is not exposed to any of the variables, and accounts for return drivers not captured by our cross-sectional model.)

In a second step, we run a time-series regression of the daily excess returns on the Russell 3000 total return index on the daily coefficients. The estimates from this regression tell us which factors were driving the market's overall returns during the period. ${ }^{11}$

\footnotetext{
${ }^{9}$ While it might at first sight seem odd to include both $\log$ market cap and the size factor exposure in the regression, both should be included because they measure different things. The size exposure measures how a given stock moves with the size factor, not the size of the firm as such-some small stocks might move like large stocks and conversely. For example, in our sample, AbbVie Inc. has a market capitalization of over $\$ 100$ billion and a positive exposure of 0.55 to the size factor.

${ }^{10}$ Obviously such a portfolio might involve significant leverage. However, since the explanatory variables remain constant through time, the underlying portfolio is identical every day; the only difference across days is the portfolio's return. Hence, rescaling the portfolio would not affect the results of our analysis.

${ }^{11}$ The overall positive market development since the election is surprising given the strong positive relation between prediction market odds of Clinton winning and the returns on all major US equity index futures before the election (Wolfers and Zitzewitz 2018). A positive shortterm aggregate market reaction to a surprise Republican
} 


\section{B. Results}

Figure 1 summarizes the results. Details are given in online Appendix Table A-2. There is a highly significant relationship between the daily coefficients on both the cash ETR and foreign revenues and overall market moves. In other words, the market tended to move upward (downward) on those days when high-tax firms outperformed (underperformed) low-tax firms. The effects are sizable: a one standard deviation greater sensitivity of stock returns to taxes on a given day is associated with 33 percent of a standard deviation increase in Russell 3000 returns.

A similar, albeit stronger, result applies for foreign revenues. The positive slope on foreign revenues shows that the market tended to go up on days where firms with large foreign exposure did better than their low foreign exposure counterparts. (Interestingly, our analysis showed that on average domestically oriented firms did better over the whole time period.) We note that these aggregate-market effects might reflect linkages between the United States and the world economy and not merely tax or trade effects and therefore warrant further study.

These results cannot prove a causal impact of the prospect for or enactment of tax cuts on the market development between Trump's election and the end of 2017. It is conceivable that omitted factors that drove variation in market returns were also correlated with the estimated coefficient on cash ETR in the daily regressions. But the findings strongly suggest that corporate taxes play an important role for aggregate stock market valuations. They also suggest that American companies' foreign exposure is important in the same way.

Presidency is in line with historical experience (Snowberg, Wolfers, and Zitzewitz 2007). Over the full term of administrations, large excess returns are realized under Democrat Presidents (Santa-Clara and Valkanov 2003). Blanchard et al. (2018) investigate potential explanations for the rise in the stock market since the election. To assess the role of tax cut expectations, they correlate weekly returns on the aggregate market with changes in the price of a prediction market contract that pays out upon passage of a corporate tax cut in 2017. This approach has the advantage that it directly uses the probability of a tax cut. However, the corresponding prediction market contract is illiquid and its price only reflects the probability of a tax cut, not its magnitude. By contrast, our method accounts for both the probability and the size of a cut.
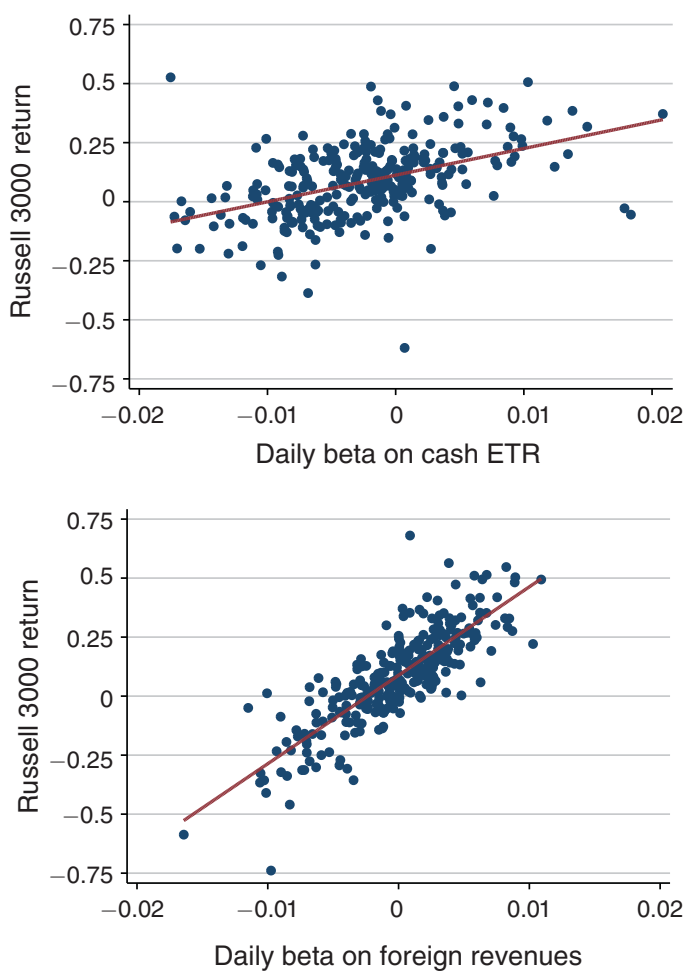

Figure 1. TaXes, Trade, and the Aggregate Market

Note: The figures show scatter plots of daily returns on the Russell 3000 total return index against coefficients on the cash ETR (top panel) and on percent foreign revenues (bottom panel) from daily cross-sectional regressions of raw stock returns on firm characteristics, controlling for all other variables shown in online Appendix Table A-2, columns 2 and 3 .

\section{Conclusion}

From Donald Trump's election to the actual passage of the TCJA, a bit more than a year later, stocks as a whole moved smartly upward. An anticipated major cut in corporate taxes, as our analysis shows, clearly played a major role. As in any boom period, some stocks did much better than others. What distinguishes this period's boom was the clear and extensive role that expected and realized policy changes had for benefits and costs to firms. A dissection of individual stock price movements in the legislative period showed high-tax firms to be big beneficiaries, and firms with significant foreign exposures to have dragged behind. In sum, the 
results confirm that taxes are a very important component of firm value.

\section{REFERENCES}

Blanchard, Olivier, Beth Anne Wilson, Mohammad Jahan-Parvar, Juan M. Londono, Chris Collins, and Thomas Pellet. 2018. "Why Has the Stock Market Risen So Much Since the Election?" Peterson Institute for International Economics Working Paper.

Santa-Clara, Pedro, and Rossen Valkanov. 2003. "The Presidential Puzzle: Political Cycles and the Stock Market." Journal of Finance 58 (5): 1841-72.

Snowberg, Erik, Justin Wolfers, and Eric Zitzewitz. 2007. "Partisan Impacts on the Economy:
Evidence from Prediction Markets and Close Elections." Quarterly Journal of Economics 122 (2): 807-29.

Wagner, Alexander F., Richard J. Zeckhauser, and Alexandre Ziegler. Forthcoming. "Company Stock Price Reactions to the 2016 Election Shock: Trump, Taxes and Trade." Journal of Financial Economics.

Wagner, Alexander F., Richard J. Zeckhauser, and Alexandre Ziegler. 2018. "Paths to Convergence: Stock Price Behavior After Donald Trump's Election.” Harvard Kennedy School Research Working Paper RWP17-039.

Wolfers, Justin, and Eric Zitzewitz. 2018. "The 'Standard Error' of Event Studies: Lessons from the 2016 Election." AEA Papers and Proceedings. https://doi.org/10.1257/ pandp.20181090. 